\title{
Effect of fungal fermentation on the nutrient digestibility of guar meal in Penaeus vannamei
}

\author{
R. JANNATHULLA, J. SYAMA DAYAL, K. AMBASANKAR AND M. MURALIDHAR \\ ICAR-Central Institute of Brackishwater Aquaculture, 75, Santhome High Road, RA Puram, Chennai \\ Tamil Nadu - 600 028, India \\ e-mail: syamdayal@rediffmail.com
}

\section{ABSTRACT}

\begin{abstract}
A 30-days indoor feeding trail was carried out to determine the nutrient digestibility of untreated and fermented guar meal (GRM) in Penaeus vannamei. The fermented guar meal was prepared by solid state fermentation using the fungus Aspergillus niger. A reference diet was formulated based on the dietary requirements of shrimp and test diets were prepared using the ingredient substitution method of reference diet and test ingredient at 7:3 ratio. Results revealed that the fungal fermentation significantly $(\mathrm{p}<0.05)$ increased dry matter digestibility of GRM from 48.86 to $54.27 \%$ and crude protein digestibility from 64.41 to $68.54 \%$. Significant $(\mathrm{p}<0.05)$ improvement was observed in the digestibility of all the amino acids with fermented GRM compared to the untreated GRM. The range of essential amino acids digestibility was increased from $59.4-69.6 \%$ to $61.5-73.6 \%$ post-fermentation. Lysine in essential amino acids and serine in nonessential amino acids showed the highest digestibility in both untreated and fermented GRM whereas a better improvement was observed with arginine $(9.79 \%)$ and glutamic acid $(8.59 \%)$ due to fermentation. The present results of increased digestibility parameters in fermented GRM were attributed to the amelioration of anti-nutritional factors and reduction of fibre fractions.
\end{abstract}

Keywords: Aspergillus niger, Digestibility, Fungal fermentation, Guar meal, Penaeus vannamei

\section{Introduction}

Commercial shrimp feeds are generally formulated based on the nutritional composition of ingredients used for feed preparation and nutrient requirement of the cultured species. Adequate knowledge on feed ingredients helps to formulate nutritionally efficient feeds for aquatic species. In shrimp feed formulation, fishmeal is included in the range of 20 to $50 \%$ (Ali et al., 2004) due to higher palatability, digestibility and presence of all the essential nutrients to fulfill the dietary requirements of the cultured species. But in the last two decades, availability of fishmeal was drastically reduced due to various climatic events (FAO, 2015) which spurred nutritionists to reduce the usage of fishmeal quantity in feed formulation. Despite the oil seed meals have primarily been evaluated as a fishmeal alternate in the diet of shrimp (Lim and Dominy, 1990; Dayal et al., 2011), there was also a concern about searching for various novel ingredients in order to increase affordability of feed ingredients. Cost of traditional plant based protein sources have increased in recent years as a result of high market demand from other feed industries (Kalanjiam et al., 2014). Among the novel ingredients identified, guar meal (GRM) is having parallel nutritional composition like other traditional plant protein sources and it is also relatively inexpensive compared to soybean meal (Rajamohammed, 2012).
The GRM is a residual byproduct left after mechanical separation of galactomannan polysaccharide gum from guar seed. Global production of guar was about 2.34 million $\mathrm{t}$ in 2014 of which $>80 \%$ was produced by India followed by Pakistan (15\%) (Guar Outlook, 2015). GRM was used to certain extent in livestock feed (Lee et al., 2005) as well as in fish feed (Asad et al., 2005; El-Saidy et al., 2005; Kalanjium et al., 2014) but its usage is very rare as an ingredient in shrimp feed. In our previous study, nutrient utilisation of GRM in the diet of Penaeus vannamei was evaluated and the results clearly indicated deleterious effects on the measures of growth, nutrient utilisation and feed efficiency due to the inclusion of GRM (Jannathulla et al., 2016). Poor performance with GRM was attributed to undesirable chemical constituents especially, anti-nutritional factors (Asad et al., 2005; Jannathulla et al., 2016). The deleterious effects of anti-nutritional factors have been reported earlier in shrimp (Lim and Dominy, 1990; Chen et al., 1996).

Microbial fermentation has been reported to be effective for enhancing the nutritional quality of plant based ingredients by partially or completely destroying the undesirable constituents (Shi et al., 2015). Most of the earlier reports on fermentation have been restricted in evaluating the limited nutrients without paying attention 
to digestibility parameters in candidate shrimp species (Hong et al., 2004; Chen et al., 2010; Jalil et al., 2015; Shi et al., 2015). Assessing digestibility is an important prerequisite to screen potential feed ingredients, which would be beneficial in developing nutritionally adequate diets as well as in reducing the waste produced by cultured species (Hajen et al., 1993). Digestibility parameters of various traditional plant based ingredients have been investigated earlier in penaeid shrimps (Piedad et al., 1990; Catacutan, 1991; Cruz-Suarez et al., 2001) but to date, there are no available literatures on digestibility of untreated and fermented GRM. Hence in the present study, the digestibility parameters of GRM were evaluated after fermentation using the fungus, Aspergillus niger in $P$. vannamei to explore the suitability of the test ingredients, in particular fermented guar meal (FGRM) in the diet of shrimp.

\section{Materials and methods}

\section{Fermentation methodology}

GRM was purchased from the local market $(n=6)$ and were ground to a particle size of $<500 \mu \mathrm{m}$. The ground materials were subsequently sterilised by autoclaving at $121^{\circ} \mathrm{C}$ for $15 \mathrm{~min}$ and subsequently hydrated with water to bring the moisture content to a level of 60 to $65 \%$. Cooled autoclaved ingredients were inoculated with A. niger (ATCC 6275; sourced from Himedia Laboratories, Mumbai, India) suspension $\left(10^{7}\right.$ spores $\left.\mathrm{ml}^{-1}\right)$ at the rate of $5 \%$ to the substrate. Fermentation was carried out at $35 \pm 1^{\circ} \mathrm{C}$ in an incubator for three days in $500 \mathrm{ml}$ Erlenmeyer flask covered with non-absorbent cotton plugs to facilitate air transfer with three sets of replications (Shi et al., 2015). At the end of fermentation, all the samples were dried at 35 to $40^{\circ} \mathrm{C}$ for $48 \mathrm{~h}$ to bring down the moisture content below $10 \%$, ground to fine particles and then stored properly in a refrigerator at $4^{\circ} \mathrm{C}$ until further use. Chemical constituents of untreated (GRM) and fermented GRM (FGRM) are presented in Table 1.

\section{Experimental diets}

A reference diet (Table 2) was formulated based on the dietary requirement of $P$. vannamei using locally available ingredients with chromic oxide $(0.5 \%)$ as an inert marker. Two test diets were prepared using $70 \%$ of reference diet and 30\% of test ingredients viz., GRM and fermented GRM according to Zhou et al. (2014). Diets were prepared by powdering the coarse ingredients listed in the formulae in a micropulveriser and passed through $250 \mu \mathrm{m}$ mesh screen. All the ingredients including fish oil and lecithin were mixed in a domestic mixer for homogenisation. Water was added to the homogenised mash at the rate of $500 \mathrm{ml} \mathrm{kg}^{-1}$ and manually kneaded into
Table 1. Effect of fungal fermentation on chemical composition ( $\%$ dry matter basis) of guar meal $(n=6 ;$ mean \pm SD)

\begin{tabular}{|c|c|c|}
\hline \multirow{2}{*}{ Treatments } & \multicolumn{2}{|c|}{ Guar meal } \\
\hline & GRM & FGRM \\
\hline \multicolumn{3}{|l|}{ Proximate composition } \\
\hline Crude protein & $52.40^{\mathrm{b}} \pm 0.16$ & $57.14^{\mathrm{a}} \pm 0.23$ \\
\hline Ether extract & $7.83^{\mathrm{a}} \pm 0.08$ & $7.82^{\mathrm{a}} \pm 0.03$ \\
\hline Crude fiber & $7.94^{\mathrm{a}} \pm 0.07$ & $6.06^{\mathrm{b}} \pm 0.08$ \\
\hline Nitrogen free extract ${ }^{1}$ & $26.43^{\mathrm{a}} \pm 0.26$ & $23.35^{\mathrm{b}} \pm 0.19$ \\
\hline Total ash & $5.40^{\mathrm{a}} \pm 0.12$ & $5.63^{\mathrm{a}} \pm 0.77$ \\
\hline \multicolumn{3}{|l|}{ Essential amino acids } \\
\hline Arginine & $6.19^{b} \pm 0.19$ & $6.70^{\mathrm{a}} \pm 0.18$ \\
\hline Histidine & $1.30^{\mathrm{b}} \pm 0.10$ & $1.52^{\mathrm{a}} \pm 0.13$ \\
\hline Isoleucine & $2.15^{\mathrm{a}} \pm 0.10$ & $2.18^{\mathrm{a}} \pm 0.09$ \\
\hline Leucine & $1.05^{\mathrm{b}} \pm 0.13$ & $1.27^{\mathrm{a}} \pm 0.06$ \\
\hline Lysine & $2.06^{\mathrm{b}} \pm 0.16$ & $3.33^{\mathrm{a}} \pm 0.17$ \\
\hline Methionine & $0.65^{\mathrm{b}} \pm 0.15$ & $1.08^{\mathrm{a}} \pm 0.10$ \\
\hline Phenylalanine & $2.20^{\mathrm{a}} \pm 0.06$ & $2.27^{\mathrm{a}} \pm 0.09$ \\
\hline Threonine & $2.47^{\mathrm{a}} \pm 0.09$ & $2.49^{\mathrm{a}} \pm 0.08$ \\
\hline Tryptophan & $0.79^{b} \pm 0.04$ & $0.86^{\mathrm{a}} \pm 0.04$ \\
\hline Valine & $2.43^{\mathrm{a}} \pm 0.06$ & $2.48^{\mathrm{a}} \pm 0.12$ \\
\hline \multicolumn{3}{|l|}{ Nonessential amino acids } \\
\hline Alanine & $1.61^{\mathrm{b}} \pm 0.07$ & $1.93^{\mathrm{a}} \pm 0.10$ \\
\hline Aspartic acid & $4.31^{\mathrm{a}} \pm 0.05$ & $4.38^{\mathrm{a}} \pm 0.05$ \\
\hline Cystine & $0.71^{\mathrm{b}} \pm 0.15$ & $1.18^{\mathrm{a}} \pm 0.15$ \\
\hline Glutamic acid & $6.54^{b} \pm 0.07$ & $6.81^{\mathrm{a}} \pm 0.05$ \\
\hline Glycine & $2.77^{b} \pm 0.12$ & $3.22^{\mathrm{a}} \pm 0.15$ \\
\hline Proline & $2.60^{\mathrm{a}} \pm 0.07$ & $2.65^{\mathrm{a}} \pm 0.07$ \\
\hline Serine & $3.59^{b} \pm 0.21$ & $4.78^{\mathrm{a}} \pm 0.18$ \\
\hline Tyrosine & $1.91^{\mathrm{b}} \pm 0.09$ & $2.18^{\mathrm{a}} \pm 0.07$ \\
\hline \multicolumn{3}{|l|}{ Fiber fractions } \\
\hline Neutral detergent fiber & $19.71^{\mathrm{a}} \pm 0.30$ & $11.59^{b} \pm 0.09$ \\
\hline Acid detergent fiber & $9.01^{\mathrm{a}} \pm 0.17$ & $7.66^{\mathrm{b}} \pm 0.11$ \\
\hline Cellulose & $7.90^{\mathrm{a}} \pm 0.25$ & $5.72^{\mathrm{b}} \pm 0.23$ \\
\hline Hemicellulose & $10.70^{\mathrm{a}} \pm 0.53$ & $3.93^{b} \pm 0.05$ \\
\hline Lignin & $1.11^{\mathrm{a}} \pm 0.09$ & $0.44^{\mathrm{b}} \pm 0.04$ \\
\hline \multicolumn{3}{|l|}{ Anti-nutritional factors } \\
\hline Phytic acid & $2.57^{\mathrm{a}} \pm 0.16$ & $1.19^{b} \pm 0.03$ \\
\hline Saponin & $2.55^{\mathrm{a}} \pm 0.05$ & $0.96^{\mathrm{b}} \pm 0.03$ \\
\hline Tannin & $0.39^{\mathrm{a}} \pm 0.01$ & $0.33^{b} \pm 0.02$ \\
\hline Guar gum & $10.99^{\mathrm{a}} \pm 0.53$ & $10.17^{\mathrm{a}} \pm 0.58$ \\
\hline
\end{tabular}

Values with the same superscript letters in the same row are not significantly different $(\mathrm{p}>0.05)$

${ }^{1}$ Calculated by difference

dough. This dough was steamed for $5 \mathrm{~min}$ at atmospheric pressure and pelleted in a table top pelletiser having $2 \mathrm{~mm}$ dia die (Dayal et al., 2003). The pellets were dried in a forced air oven at $60^{\circ} \mathrm{C}$ for $12 \mathrm{~h}$ and stored in a refrigerator until being used. The proximate and amino acids composition of experimental diets are given in Table 3 . 
Table 2. Ingredient composition of reference diet used for in vivo digestibility trials ( $\%$ as fed basis)

\begin{tabular}{ll}
\hline Ingredients & Inclusion (\%) \\
\hline Fishmeal $^{1}$ & 25.0 \\
Acetes & 12.0 \\
Prawn head & 6.0 \\
Squid meal & 4.0 \\
Corn gluten & 2.5 \\
Wheat gluten & 1.5 \\
Sesame cake & 5.0 \\
Rice bran & 3.0 \\
Broken rice & 5.0 \\
Maida & 15.0 \\
Wheat flour & 14.5 \\
Fish oil $^{1}$ & 2.0 \\
Lecithin $_{\text {Vitamin mineral pre-mix }}{ }^{2}$ & 1.0 \\
Binder & 2.0 \\
Chromium (III) oxide $^{4}$ & 1.0 \\
\hline
\end{tabular}

${ }^{1}$ Bismi Fisheries, Mayiladuthurai, Tamil Nadu, India

${ }^{2}$ Vitamins $\left(\mathrm{kg}^{-1}\right)$ : Vitamin A (20 $\left.000 \mathrm{IU}\right), \mathrm{B}_{1}$ (70 mg), $\mathrm{B}_{2}(60 \mathrm{mg})$, $\mathrm{B}_{6}(120 \mathrm{mg}), \mathrm{B}_{12}(60 \mathrm{mg}), \mathrm{C}(1000 \mathrm{mg}), \mathrm{D}_{3}(300000 \mathrm{IU})$, E (200 mg), $\mathrm{K}_{3}(7 \mathrm{mg})$, Niacin (500 mg), Folic acid (500 mg), D-calcium pantothenate $(140 \mathrm{mg})$, Biotin $(0.50 \mathrm{mg})$, Choline chloride (800 mg), Inositol (1000 mg).

${ }^{2}$ Minerals $\left(\mathrm{kg}^{-1}\right)$ : Iron (100 mg), Copper (5 mg), Zinc (50 mg), Manganese (40 mg), Selenium (20 mg), Cobalt (1 mg), Iodine (100 mg)

${ }^{3}$ Pegabind, Bentoli Agri Nutrition Asia Pvt Ltd, Singapore

${ }^{4}$ Sigma Aldrich (Cat. No: 393703 )

\section{Digestibility trails}

A 30 days digestibility trial was conducted in P. vannamei (average weight: $14.23 \pm 1.47 \mathrm{~g}$ ) procured from local farm and acclimatised to the indoor laboratory condition for 2 weeks with a control diet having 37\% of crude protein. Post-acclimatisation, shrimps were randomly distributed into a $5001(1.31 \times 0.64 \times 0.73 \mathrm{~m})$ fiberglass reinforced plastics (FRP) tank. A total of thirty shrimps were used per treatment with each treatment having three replications (ten shrimps per replication) including control group fed a reference diet. The digestibility trial was conducted in static water system to prevent the leaching of faeces (Dayal et al., 2011) however, $80 \%$ of water was exchanged daily, prior to first feeding. During the experimental period, shrimps were fed with respective diets thrice a day (at $0700 ; 1230$ and $1730 \mathrm{hrs}$ ) and the uneaten feed and other particles were removed after an hour of feeding. Faeces were gently siphoned off from the tanks on to a bolting silk cloth from second week onwards (Smith and Tabrett, 2004). The collected faeces were gently rinsed in distilled water, dried on filter paper and frozen immediately at $-20^{\circ} \mathrm{C}$ for further analysis.
In order to have a representative sample, dried faecal material of 30 days collections from each replication in a treatment were pooled to avoid possible variation and represented as one sample. From this, six replicates were taken for the analysis. The digestibility of dry matter, crude protein and amino acids were analysed according to Smith and Tabrett (2004). UV treated water was used in the present study and water quality parameters viz., salinity (19 to $\left.21 \mathrm{~g} \mathrm{l}^{-1}\right)$, temperature $\left(26.5\right.$ to $\left.28.5^{\circ} \mathrm{C}\right)$, dissolved oxygen (5.8 to $\left.7.8 \mathrm{mg} \mathrm{l}^{-1}\right), \mathrm{pH}(8$ to 8.5$)$ and total ammonianitrogen $\left(<0.1 \mathrm{mg} \mathrm{l}^{-1}\right)$ were monitored periodically following standard methods (APHA, 2012).

\section{Biochemical analysis}

Proximate composition of ingredients and experimental diets in terms of moisture, crude protein, ether extract, crude fiber and total ash were analysed as per standard methods (AOAC, 1997). Chromium content was analysed after Furukawa and Tsukahara (1966) by spectrophotometric method $(350 \mathrm{~nm})$ in both diets and faeces to calculate apparent digestibility coefficient of dry matter, crude protein and amino acids. Amino acid profiles were analysed using pre-column HPLC gradient system (Shimadzu Corp, LC-30AD) after hydrolysing the samples with $6 \mathrm{~N}$ hydrochloric acid in a sealed tube for $22 \mathrm{~h}$ at $110^{\circ} \mathrm{C}$ in an oven (Finlayson, 1964). Tryptophan, being labile to acid hydrolysis was measured after alkali hydrolysis by spectrophotometric method at $500 \mathrm{~nm}$ (Sastry and Tammuru, 1985). The partial oxidation of sulphur containing amino acids (cystine and methionine) during acid digestion was prevented using $0.1 \%$ phenol (Jajic et al., 2013). Anti-nutritional factors such as saponin (AOAC, 1997), phytic acid (Davis and Reid, 1979), tannin (Price et al., 1978) and guar gum (Das et al., 1977) were analysed by standard methods. Fiber fractions namely, neutral detergent fiber (NDF), acid detergent fiber (ADF), cellulose, hemicellulose and lignin of selected plant protein sources and experimental diets were estimated after Van Soest et al. (1991).

\section{Statistical analysis}

The data on digestibility were subjected to t-test to find significant difference if any due to fermentation. Prior to statistical evaluation, the data was checked for determining the homogeneity of variance after ascertaining the normal distribution. The entire data were analysed using SPSS version 16.0 and the statistical tests were evaluated at $5 \%$ significance $(\mathrm{p}<0.05)$.

\section{Results and discussion}

The nutritive value of ingredients varies based on the nutritional composition and hence, measuring the dry matter digestibility would be beneficial to ascertain 
Table 3. Proximate and amino acid composition of reference and test diets ( $\%$ fed basis)

\begin{tabular}{|c|c|c|c|c|}
\hline \multirow{2}{*}{ Particulars } & \multirow{2}{*}{ Reference diet } & \multicolumn{2}{|c|}{ Test diets } & \multirow{2}{*}{$\mathrm{R}^{1}$} \\
\hline & & GRM & FGRM & \\
\hline \multicolumn{5}{|l|}{ Proximate composition } \\
\hline Moisture & 7.47 & 7.35 & 7.61 & \\
\hline Crude protein & 37.42 & 39.63 & 41.13 & \\
\hline Ether extract & 7.15 & 7.40 & 7.40 & \\
\hline Crude fiber & 2.61 & 2.93 & 2.68 & \\
\hline Nitrogen free extract ${ }^{2}$ & 31.66 & 29.21 & 27.44 & \\
\hline Total ash & 13.69 & 13.48 & 13.74 & \\
\hline \multicolumn{5}{|l|}{ Essential amino acids } \\
\hline Arginine & 2.02 & 3.27 & 3.43 & 2.32 \\
\hline Histidine & 0.86 & 1.00 & 1.06 & 0.80 \\
\hline Isoleucine & 1.42 & 1.64 & 1.66 & 1.01 \\
\hline Leucine & 2.58 & 2.13 & 2.20 & 1.70 \\
\hline Lysine & 1.98 & 2.00 & 2.38 & 1.64 \\
\hline Methionine & 0.93 & 0.85 & 0.98 & 0.90 \\
\hline Phenylalanine & 1.73 & 1.88 & 1.90 & 1.40 \\
\hline Threonine & 1.42 & 1.74 & 1.74 & 1.51 \\
\hline Tryptophan & 0.42 & 0.43 & 0.47 & - \\
\hline Valine & 1.63 & 1.87 & 1.89 & 1.40 \\
\hline \multicolumn{5}{|c|}{ Nonessential amino acids } \\
\hline Alanine & 2.06 & 1.93 & 2.03 & \\
\hline Aspartic acid & 2.99 & 3.39 & 3.41 & \\
\hline Cystine & 0.49 & 0.56 & 0.70 & \\
\hline Glutamic acid & 5.49 & 5.82 & 5.90 & \\
\hline Glycine & 1.86 & 2.13 & 2.27 & \\
\hline Proline & 1.79 & 2.04 & 2.05 & \\
\hline Serine & 1.51 & 2.14 & 2.50 & \\
\hline Tyrosine & 0.38 & 0.50 & 0.52 & \\
\hline Alanine & 1.17 & 1.39 & 1.47 & \\
\hline \multicolumn{5}{|l|}{ Fiber fractions } \\
\hline Neutral detergent fiber & 29.20 & 25.82 & 23.70 & \\
\hline Acid detergent fiber & 18.46 & 15.40 & 15.08 & \\
\hline Cellulose & 2.53 & 2.63 & 2.38 & \\
\hline Hemicellulose & 10.74 & 10.41 & 8.63 & \\
\hline \multicolumn{5}{|l|}{ Anti-nutritional factors } \\
\hline Phytic acid & 0.36 & 0.93 & 0.52 & \\
\hline Saponin & 0.07 & 0.67 & 0.31 & \\
\hline Tannin & 0.15 & 0.29 & 0.21 & \\
\hline Guar gum & $\mathrm{nd}^{3}$ & 2.78 & 2.74 & \\
\hline
\end{tabular}

${ }^{1}$ Recommended levels of essential amino acids in P. vannamei (\%) according to Macias-Sancho et al. (2014)

${ }^{2}$ Calculated by difference

${ }^{3}$ Not detected

the total quantity of nutrients that were digested and absorbed (Glencross et al., 2007) since all the components of ingredients are not digested at equal proportion. In our study, dry matter digestibility of GRM (48.86\%) was lower compared to crude protein digestibility (64.41\%).
Similar results have been reported for untreated GRM in P. monodon (Rajamohammed, 2012) and the findings of Akiyama et al. (1989) suggested that it can be attributed to better assimilation of crude protein. Fungal fermentation has significantly $(\mathrm{p}<0.05)$ increased dry matter digestibility 
from 48.86 to $54.27 \%$ and crude protein digestibility from 64.41 to $68.54 \%$. The challenging digestibility problem with untreated GRM was mainly attributed to the presence of anti-nutritional factors (El-Saidy et al., 2005; Jannathulla et al., 2016). Swick and Ivey (1992) reported that phytic acid has impaired protein digestibility in aquatic species by forming phytate-protein complexes. Tannin (Makkar and Becker, 1999) and phytic acid (Helsper et al., 1993) interferes with protein digestibility by inhibiting protein hydrolytic ensymes in aquatic species. The feeding rate, growth and molting frequency of Penaeus japonicus has reduced due to the presence of saponin (Chen et al., 1996). A. niger markedly reduced the quantity of phytic acid, saponin and tannin by 53.7, 62.4 and $15.4 \%$ respectively during fermentation (Table 1) though fermentation did not influence the level of galactomannan gum. The reduction of these anti-nutritional factors post-fermentation (Table 1 and 3 ) could have contributed to the increased dry matter and crude protein digestibility in our study (Fig. 1).

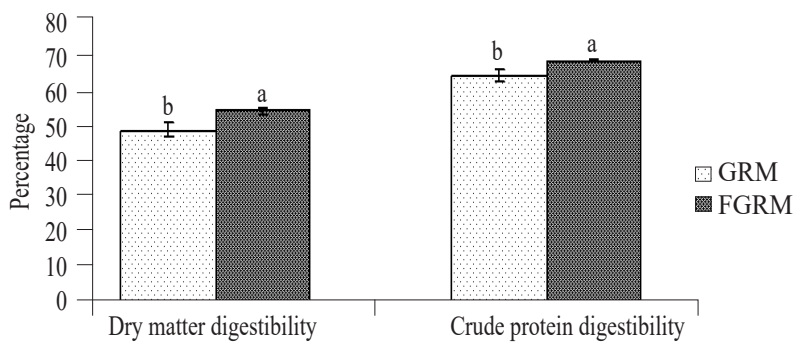

Fig. 1. Dry matter and crude protein digestibility of untreated and fermented guar meal in P. vannamei. Columns with same superscript letters between the categories are not significantly different $(\mathrm{p}>0.05)$

Similarly the poor digestibility of untreated GRM was also related to the limited capability of $P$. vannamei to digest fibrous components. Typically, GRM had considerable quantity of fiber fractions (Table 1). Bureau et al. (1999) stated that the hydrolytic enzymes responsible for the degradation of fiber fractions are scarce in mono-gastric animals including shrimp. It could be the reason for lower digestibility observed with untreated GRM in the present investigation. The fiber fractions entrap the digestible nutrients and prevent digestive enzymatic degradation of these nutrients thereby decreasing the digestibility parameters. The fibre fractions also reduce the gut transit time (Brunson et al., 1997). Lim et al. (1997) reported that $P$. vannamei had better growth and digestibility when fed with diet containing low fiber canola meal (14\%) than those fed with high fiber canola meal (28\%). Shi et al. (2015) documented that the fungus, $A$. niger is one of the beneficial microorganisms in reducing fibrous components by producing various fiber hydrolytic enzymes during fermentation. A. niger was found to produce $30 \mathrm{U} \mathrm{g}^{-1}$ of cellulase (Reddy et al., 2015), $3099 \mathrm{U} \mathrm{g}^{-1}$ of xylanase (Maciel et al., 2008) and $9 \mathrm{U} \mathrm{g}^{-1}$ of pectinase (Solis-Pereyra et al., 1996) during solid state fermentation. The reduction of fiber fraction was in the range of 15 to $62 \%$ in fermented GRM used in the present study compared to those which are untreated (Table 1). Among fiber fractions, hemicellulose (by 62\%) showed the highest reduction followed by lignin (by 59\%) and cellulose (by 27\%) which could be one of the reasons for enhancing digestibility parameters with fermented ingredient.

In comparing digestibility parameters with other traditional plant protein sources (Dayal et al., 2011; Rajamohammed, 2012), still GRM showed poor digestibility even after fermentation. Researchers have suggested that it can be attributed to the presence of gum residues (Lee et al., 2005; Kalanjiam et al., 2014). The untreated GRM used in the present study had 10.99\% of guar gum and its quantity did not significantly reduce even after fungal fermentation (10.17\%). Daskiran et al. (2004) reported that the usage of fibrolytic enzymes alleviated the deleterious effect of guar gum by increasing intestinal viscosity of animals. $A$. niger would have produced these enzymes during fermentation as earlier reported by Solis-Pereyra et al. (1996), Maciel et al. (2008) and Reddy et al. (2015). However, no reduction in gum content was noticed in our study (Table 1). Similarly, Rajamohammed (2012) also observed that there was no change in the gum quantity of GRM after enzymatic treatment using customised enzyme mixture. It could be a reason for lowered digestibility with GRM compared to other traditional plant protein sources. However, enhanced digestibility parameters with fermentation compared to untreated GRM in our study indicates the suitability of ingredients is more after fermentation.

The utilisation of protein sources depends on the amino acid composition and also on the individual amino acid digestibility. Fungal fermentation showed a significant $(\mathrm{p}<0.05)$ increase in amino acid composition expected for phenylalanine, threonine, aspartic acid and proline (Table 1). Amino acid digestibility of untreated and fermented GRM is depicted in Table 4. The digestibility range was 59.4 to $69.6 \%$ for essential amino acids and 55.2 to $73.1 \%$ for nonessential amino acid in untreated GRM. Fermentation showed a significant $(p<0.05)$ increase in the digestibility of all the amino acids in the present study and the range increased to $61.5-73.6 \%$ for essential amino acids and $57.8-76.5 \%$ for nonessential amino acids. Among amino acids, serine followed by lysine showed the highest digestibility in both untreated and fermented 
Table 4. Amino acid digestibility (\%) of untreated and fermented guar meal in $P$. vannamei $(\mathrm{n}=6 ;$ mean \pm 6$)$

\begin{tabular}{llc}
\hline Particulars & \multicolumn{2}{c}{ Ingredients digestibility } \\
\cline { 2 - 3 } & GRM & FGRM \\
\hline Essential amino acids & & \\
\hline Arginine & $62.1^{\mathrm{b}} \pm 2.9$ & $68.2^{\mathrm{a}} \pm 3.1$ \\
Histidine & $66.5^{\mathrm{b}} \pm 1.8$ & $70.0^{\mathrm{a}} \pm 2.0$ \\
Isoleucine & $61.2^{\mathrm{b}} \pm 2.8$ & $67.1^{\mathrm{a}} \pm 3.0$ \\
Leucine & $63.5^{\mathrm{b}} \pm 1.2$ & $65.7^{\mathrm{a}} \pm 1.3$ \\
Lysine & $69.6^{\mathrm{b}} \pm 2.0$ & $73.6^{\mathrm{a}} \pm 2.2$ \\
Methionine & $63.9^{\mathrm{b}} \pm 1.3$ & $66.5^{\mathrm{a}} \pm 1.5$ \\
Phenylalanine & $59.4^{\mathrm{b}} \pm 1.1$ & $61.5^{\mathrm{a}} \pm 1.3$ \\
Threonine & $66.5^{\mathrm{b}} \pm 2.0$ & $70.6^{\mathrm{a}} \pm 2.2$ \\
Tryptophan & $68.7^{\mathrm{b}} \pm 2.4$ & $73.6^{\mathrm{a}} \pm 2.6$ \\
Valine & $64.6^{\mathrm{b}} \pm 1.2$ & $66.7^{\mathrm{a}} \pm 1.4$ \\
\hline Nonessential amino acids & & \\
\hline Alanine & & \\
Aspartic acid & $55.2^{\mathrm{b}} \pm 1.3$ & $57.8^{\mathrm{a}} \pm 1.5$ \\
Cystine & $65.9^{\mathrm{b}} \pm 1.7$ & $69.2^{\mathrm{a}} \pm 1.9$ \\
Glutamic acid & $66.5^{\mathrm{b}} \pm 1.8$ & $69.9^{\mathrm{a}} \pm 1.9$ \\
Glycine & $67.5^{\mathrm{b}} \pm 2.8$ & $73.3^{\mathrm{a}} \pm 3.0$ \\
Proline & $57.9^{\mathrm{b}} \pm 1.8$ & $61.5^{\mathrm{a}} \pm 1.9$ \\
Serine & $59.7^{\mathrm{b}} \pm 1.5$ & $62.6^{\mathrm{a}} \pm 1.7$ \\
Tyrosine & $73.1^{\mathrm{b}} \pm 1.8$ & $76.5^{\mathrm{a}} \pm 2.0$ \\
\hline Va & $61.6^{\mathrm{b}} \pm 2.3$ & $66.3^{\mathrm{a}} \pm 2.4$ \\
\hline
\end{tabular}

Values with the same superscript letters in the same row are not significantly different $(\mathrm{p}>0.05)$

GRM whereas a better improvement was observed with arginine $(9.79 \%)$ in essential amino acids and glutamic acid $(8.59 \%)$ in nonessential amino acids due to fermentation. Though the quantity of phenylalanine, threonine, aspartic acid and proline did not differ significantly (Table 1), their digestibility coefficients have also increased significantly $(p<0.05)$ due to fermentation. The findings of Ash (1985) suggested that it can be due to increased availability of the respective amino acids. Better growth and nutrient utilisation observed with fermented GRM compared to untreated GRM in P. vannamei (Jannathulla et al., 2016) further confirms the present findings of increased amino acid digestibility due to fungal fermentation.

Even though there have been no reports on the in vivo amino acid digestibility regarding fermented ingredients, the results of our study are in agreement with the findings reported by Shi et al. (2015) relating to the increase in in vitro digestibility of amino acids for rapeseed meal fermented with $A$. niger. The increase of amino acids digestibility was attributed to the secretion of extra cellular proteolytic enzymes (proteases). Shi et al. (2015) reported that $A$. niger produced $>800 \mathrm{U} \mathrm{g}^{-1}$ of protease during the fermentation of rapeseed meal. Among amino acids, both untreated and fermented ingredients have shown a poor digestibility for alanine and glycine (Table 4) and the findings of Akiyama et al. (1989) suggested that it can be due to the secretion of chitinous peritropic membrane which surrounds the faeces. The same was in agreement with the findings of Dayal et al. (2011) for sunflower oil cake (SFC) in the diet of $P$. monodon, who also reported that chitin had a higher content of alanine and glycine than other amino acids.

Results of the present study demonstrated that $P$. vannamei efficiently digests fermented GRM compared to the respective untreated ingredient as such. It indicates that the fermented plant protein source has a greater potential to be used as a protein source rather than as untreated material in the diet of shrimp. Hence the present study concludes that the fermented ingredients would help to formulate high quality feed rather fulfilling dietary quantitative requirements in the diet of shrimp.

\section{Acknowledgements}

Authors are thankful to Dr. K. K. Vijayan, Director, ICAR-Central Institute of Brackishwater Aquaculture, Chennai, India for providing necessary facilities to carry out the present work. Indian Council of Agricultural Research (ICAR), New Delhi, India is duly acknowledged for the financial support through the project, National Innovation in Climate Resilient Agriculture (NICRA).

\section{References}

Akiyama, D. M., Coelho, S., Lawrence, A. L. and Roberson, E. H. 1989. Apparent digestibility of feedstuffs by the marine shrimp Penaeus vannamei (Boone). Nippon Suisan Gakkaishi, 55: 91-98.

Ali, S. A., Syama Dayal, J. and Ambasankar, K. 2004. India study: Corn gluten can partially replace fishmeal in white shrimp feed. Global aquaculture advocate, $60 \mathrm{pp}$.

AOAC 1997. Official methods of analysis of Association of Analytical Chemists, $18^{\text {th }}$ edn. Association of Official Analytical Chemists, Benjamin Franklin Station, Washington DC, USA.

APHA 2012. Standard methods for the examination of water and waste water, $22^{\text {nd }}$ edn. American Public Health Association, New York, USA.

Asad, F., Salim, M., Shahzad, M. and Noreen, U. 2005. Estimation of apparent digestibility coefficient of guar, canola and meat meal for Labeo rohita. Int. J. Agri. Biol., 7: 816-819.

Ash, R. 1985. Protein digestion and absorption. In: Cowey, C. B., Mackie, A. M. and Bell, J. G. (Eds.), Nutrition and feeding in fish. Academic Press Inc., Orlando, FL, USA, p. 68-93.

Brunson, J. F., Romaire, R. P. and Reigh, R. C. 1997. Apparent digestibility of selected ingredients in diets for white shrimp, Penaeus setiferus L. Aquac. Nutr., 3: 9-16. 
Bureau, D. P., Harris, A. M. and Cho, C. Y. 1999. Apparent digestibility of rendered animal protein ingredients for rainbow trout (Oncorhynchus mykiss). Aquaculture, 180: $345-358$

Catacutan, M. R. 1991. Apparent digestibility of diets with various carbohydrate levels and the growth response of Penaeus monodon. Aquaculture, 95: 89-96.

Chen, C. C., Shih, Y. C., Chiou, P. W. S. and Yu, B. 2010. Evaluating nutritional quality of single stage and two stage-fermented soybean meal. Asian-Aust. J. Anim. Sci., 23: 598-606.

Chen, J. C., Chen, K. W. and Chen, J. M. 1996. Effects of saponin on survival, growth, molting and feeding of Penaeus japonicus juveniles. Aquaculture, 144: 165-175.

Cruz-Suarez, L. E., Ricque-Marie, D., Tapia-Salazar, M., McCallum, I. M. and Hickling, D. 2001. Assessment of differently processed feed pea (Pisum sativum) meals and canola meal (Brassica sp.) in diets for blue shrimp (Litopenaeus stylirostris). Aquaculture, 196: 87-104.

Das, B., Arora, S. K. and Luthra, Y. P. 1977. A rapid method for determination of gum in guar [Cyamopsis tetragonoloba (L.) Taub]. Proceedings of first ICAR Guar Research Workshop, Jodhpur, India, p. 117-123.

Daskiran, M., Teeter, R. G., Fodge, D. and Hsiao, H. Y. 2004. An evaluation of endo- $\beta$-D-mannanase (Hemicell) effects on broiler performance and energy use in diets varying in $\beta$-mannan content. Poult. Sci., 83: 662-668.

Davies, N. and Reid, H. 1979. An evaluation of the phytate, zinc, copper, iron and manganese contents of and $\mathrm{Zn}$ availability from, soya-based textured-vegetableprotein meat-substitutes or meat-extenders. Br. J. Nutr., 41: 579-589.

Dayal, J. S., Ahamad Ali, S., Ambasankar, K. and Singh, P. 2003. Effect of dietary protein level on its in vitro and in vivo digestibility in the tiger shrimp Penaeus monodon (Crustacea: Penaeidae). Indian J. Mar. Sci., 32: 151-155.

Dayal, J. S., Rajaram, V., Ambasankar, K. and Ahamad Ali, S. 2011. Sunflower oil cake as a replacement for fishmeal in feeds of tiger Shrimp, Penaeus monodon reared in tanks and in net cages. Indian J. Mar. Sci., 40: 460-470.

El-Saidy, S. D., Deyab, M., Gaber, M. M. and Abd-Elshafy, A. S. 2005. Evaluation of cluster bean meal, Cyamposis fefrugonoloba as a dietary protein source for common carp Cyprinus carpio L. J. World Aquac. Soc., 36: 311-319.

FAO 2015. Summary tables of fishery statistics: Capture, aquaculture, commodity and food balance sheets. Food and Agriculture Organisation of the United Nations. Fisheries and Aquaculture Department. http://www.fao.org/fishery/ statistics/en (Accessed 14 June 2016)

Finlayson, A. J. 1964. Amino acid recovering in the analysis of some feed samples. Can. J. Plant Sci., 45: 184-188.
Furukawa and Tsukahara 1966. On the acid digestion method for determination of chromic oxide as an index substance in the study of digestibility of fish feed. Bull. Jpn. Soc. Sci. Fish., 32: 207-217.

Glencross, B. D., Booth, M. and Allan, G. L. 2007. A feed is only as good as its ingredients - a review of ingredient evaluation strategies for aquaculture feeds. Aquac. Nutr., 13: 7-34.

Guar Outlook 2015. Guar industry outlook. http://ccsniam.gov. in/images/pdfs/GUAR Booklet 03122013.pdf. (Accessed 27 March 2016).

Hajen, W. E., Beames, R. M., Higgs, D. A. and Dosanjh, B. S. 1993. Digestibility of various feedstuffs by post-juvenile chinook salmon (Oncorhynchus tshawytscha) in seawater. 1. Validation of technique. Aquaculture, 112: 321-332.

Helsper, J. P., Hoogendijk, J. M., Van Norel, A. and Kolodziej, H. 1993. Characterisation and trypsin inhibitor activity of proanthocyanidins from Vicia faba. Phytochemistry, 34: $1255-1260$.

Hong, K. J., Lee, C. H. and Kim, S. W. 2004. Aspergillus oryzae GB-107 fermentation improves nutritional quality of food soybeans and feed soybean meals. J. Med. Food, 7: 430-436.

Jajic, I., Krstovic, S., Glamocis, D., Jaksis, S. and Abramovic, B 2013. Validation of an HPLC method for the determination of amino acids in feed. J. Serb. Chem. Soc., 78: 839-850.

Jalil, A. A., Abdullah, N., Alimon, A. R. and Abd-Aziz, S. 2015. Nutrient enhancement of ground sago (Metroxylon sagu Rottboll) pith by solid state fermentation with Rhizopus oligosporus for poultry feed. J. Food Res., 4: 1-15.

Jannathulla, R., Syama Dayal, J., Ambasankar, K. and Muralidhar, M. 2016. Evaluation of fungal fermented guar meal in the diet of Penaeus vannamei. In: Kaliwal, B. B., Pandey, B. N. and Kulkarni, G. K. (Eds.), Role of animal science in national development, Nanotechnology in aquaculture. Today and Tomorrow's Printers and Publishers, New Delhi, India, p. 51-62.

Kalanjiam, M. A., Malaikozhundan, B., Girija, V., Gobi, N and Vaseeharan, B. 2014. Effect of guar (Cyamopsis tetragonolobus) meal based diets on growth performance and feed utilisation in Asian catfish, Pangasianodon hypophthalmus fingerlings. J. Fish. Soc. Taiwan, 41: 135-144.

Lee, J. T., Connor-Appleton, S., Bailey, C. A. and Cartwright, A. L. 2005. Effects of guar meal byproduct with and without beta-mannanase Hemicell on broiler performance. Poult. Sci., 84: 1261-1267.

Lim, C. and Dominy, W. 1990. Evaluation of soybean meal as a replacement for marine animal protein in diets for shrimp (Penaeus vannamei). Aquaculture, 87: 53-63.

Lim, C., Beames, R. M., Eales, J. G., Prendergast, A. F., McLeese, J. M., Shearer, K. D. and Higgs, D. A. 1997. 
Nutritive values of low and high fiber canola meals for shrimp (Penaeus vannamei). Aquac. Nutr., 3: 269-279.

Macias-Sancho, J., Poersch, L. H., Bauer, W., Romano, L. A., Wasielesky, W. and Tesser, M. B. 2014. Fishmeal substitution with Arthrospira (Spirulina platensis) in a practical diet for Litopenaeus vannamei: effects on growth and immunological parameters. Aquaculture, 426: 120-125.

Maciel, G. M., Vandenberghe, D. S. L. P., Haminiuk, C. W. I., Fendrich, R. C., Bianca, D. B. E., Brandalize, D. S. T. Q., Pandey, A. and Soccol, C. R. 2008. Xylanase production by Aspergillus niger LPB 326 in solid-state fermentation using statistical experimental designs. Food Technol. Biotechnol., 46: 183-189.

Makkar, H. P. and Becker, K. 1999. Nutritional studies on rats and fish (carp Cyprinus carpio) fed diets containing unheated and heated Jatropha curcas meal of a non-toxic provenance. Plant Foods Hum. Nutr., 53: 183-192.

Piedad-Pascual, F., Cruz, E. M. and Sumalangcay, A. 1990. Supplemental feeding of Penaeus monodon juveniles with diets containing various levels of defatted soybean meal. Aquaculture, 89: 183-191.

Price, M. L., Van Scoyoc, S. and Butler, L. G. 1978. A critical evaluation of the vanillin reaction as an assay for tannin in sorghum grain. J. Agr. Food Chem., 26: 1214-1218.

Rajamohammed, M. 2012. Exploring novel ingredients and investigations on the role of exogenous enzymes in maximising the use of alternate plant protein sources in the diet of tiger shrimp, Penaeus monodon. Ph. D. dissertation, University of Madras, India.

Reddy, G. P. K., Narasimha, G., Kumar, K. D., Ramanjaneyulu, G., Ramya, A., Kumari, B. S. S. and Reddy, B. R. 2015.
Cellulase production by Aspergillus niger on different natural lignocellulosic substrates. Int. J. Curr. Microbiol. App. Sci., 4: 835-845.

Sastry, C. S. P. and Tammuru, M. K. 1985. Spectrophotometric determination of tryptophan in protein. J. Food Sci. Technol., 22: 146-147.

Shi, C., He, J., Yu, J., Yu, B., Huang, Z., Mao, X., Zheng, P. and Chen, P. 2015. Solid state fermentation of rapeseed cake with Aspergillus niger for degrading glucosinolates and upgrading nutritional value. J. Anim. Sci. Biotechnol., 6: 13-19.

Smith, D. M. and Tabrett, S. J. 2004. Accurate measurement of in vivo digestibility of shrimp feeds. Aquaculture, 232: $563-580$

Solis-Pereyra, S., Favela-Torres, E., Gutierrez-Rojas, M., Roussos, S., Saucedo-Castaneda, G., Gunasekaran, P. and Viniegra-Gonzalez, G. 1996. Production of pectinases by Aspergillus niger in solid state fermentation at high initial glucose concentrations. World J. Microbiol. Biotechnol., 12: $257-260$

Swick, R. A. and Ivey, R. J. 1992. The value of improving phosphorus retention. Feed Management, 43: 8-17.

Van Soest, P. J., Robertson, J. B. and Lewis, B. A. 1991. Methods for dietary fiber, neutral detergent fiber and non-starch polysaccharides in relation to animal nutrition. J. Dairy Sci., 74: 3583-3597.

Zhou, Y. G., Davis, D. A. and Buentello, A. 2014. Use of new soybean varieties in practical diets for the Pacific white shrimp, Litopenaeus vannamei. Aquac. Nutr., 21: 635-643. 